\title{
Forschungsnotizen
}

\author{
Johannes Huinink, Josef Brüderl, Bernhard Nauck, Sabine Walper, \\ Laura Castiglioni \& Michael Feldhaus
}

\section{Panel Analysis of Intimate Relationships and Family Dynamics (pairfam): Conceptual framework and design}

\author{
Panel Analysis of Intimate Relationships and Family Dynamics (pairfam): \\ konzeptioneller Rahmen und Forschungsdesign
}

\begin{abstract}
:
This article introduces the DFG-funded "Panel Analysis of Intimate Relationships and Family Dynamics" (pairfam) study, which was initiated to provide an extended empirical basis for advances in family research. Within the context of challenges in couples and family research, we address the major substantive fields covered by the pairfam panel: couple dynamics and partnership stability, childbearing, parenting and child development, and intergenerational relationships. Then we present the conceptual framework and survey design of pairfam. The panel started with about 4,000 respondents (anchors) in each of three birth cohorts: 1991-1993, 1981-1983, and 1971-1973. The panel also includes anchors' partners. From the second wave onwards parents and children of anchors are included. The policy of pairfam with regard to the provision of scientific use files and data distribution are discussed in the concluding remarks.
\end{abstract}

Key words: children, couples, family research, Germany, panel study, pairfam, parenting, partnership

\begin{abstract}
Zusammenfassung:
Dieser Beitrag stellt das deutsche Beziehungsund Familienpanel (pairfam) vor, das eine empirische Basis für Fortschritte in der Beziehungsund Familienforschung bieten soll. Vor dem Hintergrund zentraler Herausforderungen in der Partnerschafts- und Familienforschung werden Themenschwerpunkte, der konzeptuelle Rahmen und das Design des pairfam-Projekts vorgestellt. Inhaltlich fokussiert werden Fragen der Aufnahme, Gestaltung und Beendigung von Partnerschaftsbeziehungen, Elternschaftsentscheidungen bei Familiengründung und -erweiterung, Erziehung und Eltern-Kind-Beziehungen sowie Intergenerationenbeziehungen. Befragungsteilnehmer waren in der ersten Erhebungswelle je rund 4.000 Jugendliche (geboren 1991-93), junge Erwachsene (geboren 1981-83) und Erwachsene im mittleren Lebensalter (geboren 1971-73) sowie nach Möglichkeit auch deren Partner/in. Ab der zweiten Erhebungswelle werden auch Eltern und Kinder einbezogen. Am Ende des Beitrages werden einige Angaben zur Distribution der Daten als scientific use file gemacht.
\end{abstract}

Schlagwörter: Erziehung, Familienforschung, Deutschland, Kinder, Paarbeziehungen, Panelstudie, pairfam, Partnerschaft 


\section{Introduction}

In the past decades, considerable progress has been made in family research. Sociological and demographic research that monitors changing family forms and living arrangements has gone beyond household boundaries in order to capture the complexity of multi-local family systems as they arise from migration, mobility, divorce, and intergenerational links across households (Peuckert 2008). Economic and sociological research not only points to the institutional and socioeconomic conditions of family life, but also addresses the exchange of support within family networks and the negotiation of limited resources within family systems (Conger/Rueter/Conger 2000; Kohli/Albertini/Künemund 2010). Psychological research provides a rich picture of family dynamics as evolving from family members' mutual expectations, individual cognitions, emotions, and behaviors and vice versa (Bodenmann 2006; Walsh 2003). And medical research along with other disciplines seeks to shed light on links between family risks and resources, health-related life styles, and family members' well-being.

Yet, the complexity of linkages across the domains of family life and levels of analysis is not fully understood. The need for interdisciplinary cooperation has been increasingly recognized as a powerful tool to understand the complexity of family development and family dynamics in social, legal, economic, and cultural contexts and to shed light on the interplay between individual experiences, dispositions, behaviors, and well-being as they mutually influence each other in the context of family.

The aim of this article is to provide an overview of the main features of the German "Panel Analysis of Intimate Relationships and Family Dynamics" (pairfam) study, which shall provide an empirical basis for achieving further improvements in understanding couples and family dynamics. The study is based on the notion that progress in family research strongly depends on sharing and conjoining expertise developed in the various disciplines, developing integrative theoretical perspectives, and employing longitudinal approaches with a large, representative data base and a broad array of information. So far, large-scale longitudinal studies on union formation and dissolution, fertility, or intergenerational relationships mainly focus on economic and socio-structural variables and pay less attention to psychological factors that would allow family-related decisionmaking processes to be modeled in detail. While psychological research does generate rich data, these are often derived from small samples or within study designs that fail to integrate socio-structural variables sufficiently.

Employing a prospective design that covers the age span from adolescence to late adulthood and that comprises multiple generations, the project will allow investigation into developmental issues, differential trajectories in relationship development, and mutual influences among members. It will also allow investigators to address a variety of contextual conditions in the proximal and distal environment. The pairfam project has begun collecting a wide range of data on an annual basis for three age cohorts, starting in 2008/2009 with a sample of 12,400 participants in adolescence, young adulthood, and middle adulthood. A joint initiative of a group of family researchers from various disciplines made this possible. In 2004, the Priority Program 1161 "Beziehungs- und Familienentwicklung [Relationship and Family Development]," funded by the German Research Foundation, supported the infrastructure needed to prepare this new German panel study. Between 2004 and 2008, ap- 
propriate instruments for data collection as well as the conceptual framework of pairfam were developed (Feldhaus/Huinink 2008; Walper/ Wendt 2010).

In the following sections, we first identify some challenges in family research, from which we derived a research agenda in four major fields of inquiry. This agenda guided the design of the pairfam panel. Then we present the conceptual framework of pairfam, describe the contents of the panel and explain the complex multi-actor design of the study in greater detail. The policy of pairfam with regard to the provision of scientific use files and the data distribution are discussed in the concluding remarks.

\section{Challenges of current research on couples and family dynamics}

Families are far from being a clear-cut set of people, and even couples have become less "visible", given decreased institutionalization of partnership relations. While this already poses considerable demands for partnership and family research, even more complexity results from the multi-faceted interplay of couples and family dynamics with individual development, activities in other life domains, social context, and societal conditions that frame the pursuit of subjective well-being during the life course (Huinink 2005; Seltzer et al. 2005). In order to describe the starting point for implementing the pairfam panel, we address the following five kinds of challenges that need to be overcome in order to achieve further progress in couples and family dynamics research.

1. Descriptive demands: Given the expanding variety in living arrangements and family structures over time, the descriptive information available from demographic family research has to be updated and differentiated steadily so as to capture continuity and change in relationship arrangements. More specifically, differentiated descriptive information has to account for less institutionalized types of relationships such as unmarried partners in "living apart together" arrangements, stepchild relations, grandparent-child relations, non-normative types of relationships (e.g. homosexual partnership), and diversified patterns of family roles including children's relationships with any number of non-traditional parental figures such as a parent not living in the household, married and unmarried stepparents, or a single parent's new partner. It must also account for patterns of couple and family relationships that span stages of relationship development, different households, or geographic distance due to the mobility of partners and family members.

2. Individual perspectives on linked lives: While family members typically hold individual views regarding their relationships, research on couples and families needs also to include partners' perspectives. This is important not only to be able to identify shared as well as distinct or even contradictory experiences, but also to allow for a fuller understanding of mutual interdependence in decision making and action. Elder's concept of "linked lives" (Elder 1994) alerts us to the fact that family members' lives are interdependent. Individual actors affect each other through their behavior, be it as partners, as siblings, or as parents in relationships with young or adult children. Only multi-actor designs and adequate methodological approaches (e.g. dyadic data analyses) are suited to capture these processes adequately. 
3. Cross-domain effects: Family life is closely intertwined with other domains of the life course. Families are confronted with expectations in the labor market and school settings. Family life may also set the stage for social participation in other societal contexts, and it has long been recognized as a major context for recreation. To understand couples and family dynamics as part of the multidimensional life course more adequately, special attention needs to be paid to the likely mutual influences between these spheres as well as to the logic of context-bound individual action in the pursuit of individual goals. More specifically, it is necessary to understand how actors allocate their resources and engagement in these fields of activities (e.g. family life and work), aiming to achieve and sustain subjective well-being. Selective investments in close relationships and other domains of life may compete, support, or complement each other. Alternatively, they may substitute for each other, as when friendship networks or social relations at work substitute for strong family ties. However, we still know very little about whether family benefits can be substituted, as these are assumed to provide particularly close, personal, and authentic interactions (Huinink 1995).

4. Selection and adaptation across the life course. Family processes are typically recursive, and mechanisms of selection and adaptation make it difficult to specify causeeffect relationships within them. They are, however, of essential importance as they can be found across the entire life course (Lesthaeghe 2002). For example, values and intentions may influence the probability of family-related transitions such as marriage or childbearing (selection), while at the same time such transitions probably reshape the actors' family-related values (adaptation). Individual norms, attitudes, and cognitive scripts of the future life course - which typically emerge in earlier life phases are particularly likely candidates for selective pattern determination (Mayer 2009).

5. Multilevel context and social embeddedness: Just as family life is linked to other domains of life, families are embedded in the larger social, economic, and cultural contexts. These affect their structure and functioning. The multilevel embeddedness of union and family development is an essential characteristic that must be addressed in order to adequately understand the dynamics of couple and family relations. Studies investigating the effects of economic conditions and societal institutions on couples and family dynamics in national, regional, or local environments are important. The same holds true for the embeddedness of relationships (for example, couples or parent-child dyads) in social and kinship networks.

Focusing on these more conceptual issues, the next section will highlight aspects of our agenda with regard to the four major substantive fields of couples and family research covered by the pairfam panel: (1) couple dynamics and partnership stability, (2) childbearing, (3) parenting and child development, and (4) intergenerational relationships. These research fields address the major domains of family life that are of particular salience due to recent demographic changes such as reduced marriage rates, increased cohabitation, high rates of separation/divorce, reduced fertility rates, increased unmarried childbearing and the increased longevity that has lengthened the shared life span between generations. Furthermore, understanding the causes and consequences of diverse patterns of relationship quality for the well-being of children, adolescents, and adults is essential for policy planning and designing appropriate interventions. 


\section{Research isues in the major content domains of pairfam}

\subsection{Couple dynamics and partnership stability}

Patterns of union formation and the dynamics of couple relationships have changed considerably during the last 50 years (see Walper/Wendt 2010b). Romantic involvement starts earlier in the life course while marriage has become postponed if not replaced by unmarried unions (Hoehn/Avramov/Kotovska, 2008). As the latter have become more prevalent across all age groups and as mobility demands increased, hybrid forms of living arrangements involving two (or more) households have gained relevance. Partnership stability has decreased, and even after separation former partners are expected to cooperate for the sake of co-parenting (Pryor/Rodgers 2001; Smart/Neale/Wade 2001). Many of these changes in couple relationships are not yet adequately reflected in current demographic descriptions. For example, although increasing attention is being paid to commuting couples and the diverse arrangements of "living apart together" in partnerships (Schneider/Limmer/Ruckdeschel 2002; Schneider/Meil 2009), the complex spatial and temporal structures of such arrangements still have to be spelled out. Accordingly, there is a need for updating our descriptive knowledge about couples' living arrangements, employing more refined information particularly with respect to mobility regimes and paying attention to how these relate to trajectories of couple development as they may be identified in longitudinal perspective (Brüderl 2004).

Longitudinal analyses are indispensable not only for identifying more or less typical trajectories of institutionalization in partnership development but also for addressing issues of causation. In partnership research, additional challenges arise from the notion that partners' life courses have to be "co-organized" (Blossfeld/Drobnič 2002). Each partner's attitudes and behaviors are context for the other's decisions and vice versa (linked lives). In order to shed light on how partners affect each other (with regard to educational or occupational development or to family planning, for example), coupled life courses must be analyzed with appropriate dyadic data and related statistical models (Lyons/Sayer 2005). So far, reverse influences of partners on each other have only begun to be more broadly addressed by current research.

Psychological analyses suggest that the following factors play major roles in partnership quality and stability: previous relationship experiences, personal resources and skills in navigating through emotionally charged social encounters, the kinds of causes each partner attributes to the other's behavior, both partners' conflict tactics, and their dyadic stress management (Karney/Bradbury 1995; Bodenmann et al. 2007; Fincham 2004; Randall \& Bodenmann 2009). More recently, the traditional focus on destructive forces in relationships has shifted to a focus on repair mechanisms which allow couples to overcome crises and promote resilience in their relationships. Such repair mechanisms include, for example, those stemming from religious beliefs or partners' willingness to forgive and make sacrifices (Fincham/Stanley/Beach 2007). While it would seem timely to bridge such micro-level perspectives with the previously outlined perspectives on macrolevel trends, suitable interdisciplinary approaches are slow to rise. Yet, they seem most promising for allowing adequately broad and at the same time differentiated analyses of how partnership relations develop, be it with regard to the quality of the relationship, to 
issues of labor division, to the internal power distribution, or to the stability of the relationship (Arránz Becker 2008).

One guiding assumption is that cross-domain effects increase the cost of living in an intimate relationship or in a marriage in modern welfare societies (Peuckert 2008). Successfully combining commitment in an intimate relationship with individual flexibility, autonomy, and mobility in one's career or other domains of the life course is difficult. Although intimate relationships might even gain relevance for individual well-being, actors seem less likely to invest in partnership relations. Rather, they tend to minimize the restrictions that arise from the binding forces of intimate relationships. For most individuals up to midadulthood, living alone has become more attractive (Lengerer/Klein 2007), most likely because normative barriers have been lowered and the instrumental benefits of common householding have decreased. In order to understand the logic of such choices, not only must general social trends be outlined, but conflicting life goals and options for replacing the social benefits typically derived from long-term partnerships have to be identified. While such conflicting goals and competing options may contribute to the decline of marriage and the instability of unions, they do not guide all social groups or individuals in the same manner. For example, regional differences in marriage behavior suggest that cultural factors still contribute to diversity in union formation and development (Hank 2003b).

To pay adequate attention to the multilevel contexts of union formation and particularly of couple development is a challenging task that has not been well resolved so far in part due to the fact that sociological research in this field is quite rare (Hill 2004). Marriage and partner markets have been restructured socially and include new arenas of meeting and mating. Living conditions as well as expectations regarding satisfying relationships have changed (Amato/Booth/Johnson 2007), creating new disparities between reality and expectations. For example, the now widely-accepted egalitarianism pertaining to gender norms is hard to reconcile with the remarkably stable gender roles in the division of household tasks as observable in parents' every day life in Germany (Huinink/Roehler 2005). In seeking to understand the decisions involved in partnership formation and couple development, attention must be paid to the larger context of changing partner markets and today's life course regimes, but also to how these intersect with both partners' individual dispositions and opportunities.

With respect to relevant biographical experiences in the family context, some progress has been made in identifying aspects of intergenerational transmission in the areas of partnership quality and stability (Amato 1996; Diekmann/Engelhardt 1999; Diefenbach 2000). This is particularly true for attachment research (Grossmann/Grossmann 2004; Miculincer/Goodman 2006). However, it is not yet fully understood to what extent and through which processes the organization of one's intimate relationships is guided by early experiences and how these compete with current experiences and events in various life domains. For example, issues of gender constellation in intergenerational role learning seem to be significant, but these need to be explored in further detail (Walper et al. 2008). To understand the influence of biographical experiences in other relationship contexts, a broad array of information about past and present relationships with parents, friends, and previous romantic partners has to be provided prospectively.

The pairfam project seeks to enable such analyses by taking a differentiated look not only at various aspects of partnership quality (intimacy, autonomy, emotional security 
etc.) or of subjective quality, dyadic coping, and conflict solving behavior as experienced and played out by both partners. It also focuses on personal expectations in terms of hopes and fears regarding a partnership, personality and skills, social networks and the quality of other significant relationships.

\subsection{Childbearing}

Processes of family formation and extension are embedded in a large variety of living arrangements and social network structures. Partnership and family transitions seem to follow pluralized patterns as well (Peuckert 2008). The detailed description of those patterns over the life course and in cohorts comparison is of substantial relevance. As in the case of couples dynamics, more differentiated information is needed to provide a better view of the variability of family structures in the future. In the analysis of fertility-related decision making (intention and timing), individual expectations about the welfare gains and losses associated with having children as compared to other options of achieving and sustaining subjective well-being over the life course have to be considered (Liefbroer 2005; Huinink/Feldhaus 2009). However, fertility decisions usually require two individuals to agree (linked lives). If couples do not share childbearing orientations, family formation or enlargement is likely to be postponed (Kurz 2005; Miller/Severy/Pasta 2004). Dyadic models of the interdependence of couples' fertility orientations help us to understand the relevance of this issue (Stein/Pavetic 2008).

Parenthood competes with other options in the life course such as pursuing a career, material prosperity, and personal autonomy. Cross-domain effects have to be expected. The relationship between education or labor force participation and family formation has already been studied extensively, but it is still not completely understood (Rindfuss/ Brewster 1996; Schröder/Brüderl 2008; Schröder/Pforr 2009). Research on the relationship between unemployment of women and fertility shows inconsistent or even contradictory findings (Kreyenfeld 2003; Brose 2008). However, a man's or woman's decision to have a child depends on their expectations regarding the possibility of reconciling family activities with activities in other life domains. An important question is to what degree individuals would reduce their engagement in other life domains in favor of raising children and vice versa. This refers to the general question of substitution and complementarity in personal investments, which has been addressed only rarely so far (Diewald 2003).

Personal dispositions and normative aspects of decisions regarding parenthood are highly relevant factors (Nauck 2007). Couples may neglect the long-term consequences of parenthood and do not compare the costs and benefits of children to other domains of welfare production in a purely rational manner. Personal values and preferences regarding marriage, parenthood, and activities in other domains of the life course presumably matter a great deal. However, the significance of value orientations and attitudes for familyrelated decisions has not been as thoroughly studied as have socio-structural factors such as social status or education. In particular, value-related selection effects and value adaptation cannot not be distinguished without prospective data. Those kinds of analyses require appropriate panel data (Lesthaeghe 2002). 
Theories agree that in modern societies the psychological-emotional benefits of having children (affect, identity, and generativity) dominate other kinds of benefits (Nauck 2001). Accordingly, parents should be motivated to invest more in the "quality" of children (e.g. education) than in the "quantity" of children (Becker 1991), even as aspirations in regard to children's "quantity" should rise. At the same time, couples only consider becoming parents if they feel mature enough to take over responsibility for children (Müller-Burhop 2008). In addition, certainty about one's future biography should be of major relevance. Questions of why and when partners do or do not feel ready for children have yet to be answered (Liefbroer 2009). Couples may repeatedly put off the decision to have a child. By doing so, they might reduce both aspiration levels and their anticipation of the consequences of parenthood as they get older and start hearing their biological clock ticking. Or they "slide" into voluntary or involuntary childlessness and adapt their value system in an affirmative way. The question of involuntarily childlessness because of medical reasons is assumed to gain relevance (Stöbel-Richter et al. 2008; Zeller-Steinbrich 2008). Large scale longitudinal studies on this complex aspects are still missing.

The multilevel context of decisions for parenthood has been shown to be decisive in many comparative studies. In countries with strong policies favoring the reconciliation of work and family, different patterns of family formation are found than in countries like Germany that have weaker policies. However, cultural factors may be just as important for fertility-related behavior as are other dimensions (Lesthaege/Surkyn 2004). In particular, regional differences in birth rates may reflect differences in culturally framed family-related decision making. There has been little research on this topic (Hank 2001, 2003a, 2003b). Finally, the aspect of embeddedness in social networks and kin structures has to be considered. They may provide financial or emotional support or offer help for child care. Network partners communicate special norms and values and exemplify a special life style (Bernardi/Keim/von der Lippe 2007; Bühler 2008). This means that social networks may strengthen or reduce aspiration levels. They may affect the hopes and fears related to parenthood or put pressure on potential parents. Up to now, the influence of social networks on fertility decisions has been mainly observed in small-scale qualitative studies or with cross-sectional data.

\subsection{Parenting and child development}

Parenting is considered to be the most influential factor in children's social development (Franiek/Reichle 2007; Gabriel/Bodenmann 2006; Petermann/Petermann 2006; Reichle/ Gloger-Tippelt 2007). Theoretically, parenting is seen as goal-oriented action that serves to encourage desired behavior patterns and dispositions (or hinder or reduce undesired behaviors and dispositions) in the child (Fuhrer 2005). This focus is most common in research concerning parenting goals. With respect to description, much attention has been paid to parents' child-rearing goals and how these goals have changed in the general population or in certain subgroups. Related studies demonstrate a change process within which conformity values take a backseat while values of self-actualization focusing on children's autonomy and self-determination take on an increasingly prominent position (Hillmann 2003). However, closer analyses of causal processes based on longitudinal data are rare (Schneewind/Ruppert 1995). Given that most data on parenting goals are cross- 
sectional, little is known about relevant factors and experiences which may guide the adaptation of goals to external conditions, the partner's parenting values, other social influences or interaction with the child in question.

Most research on parenting goals disregards the dyadic context of parenting (linked lives) and provides little insight in adaptive processes among couples as they develop shared parenting strategies. Surprisingly, the role of interparental cooperation and coparenting has long been neglected. While issues of co-parenting have a somewhat longer tradition in research on divorced families, only recently have they been more intensively studied for nuclear families (Teubert/Pinquart 2009). Furthermore, the approaches taken in this research area are mostly narrowly focused and rarely allow comparisons with values in other life domains.

A prominent issue in research on parenting is the identification of core dimensions of parents' behavior and attitudes regarding children that influence children's well-being in a more or less stable manner (Skinner/Johnson/Snyder 2005). Most parsimoniously, the two dimensions of warmth and control have been identified as relevant (Maccoby/ Martin 1983). Based on them, four parenting styles are distinguished: authoritative, authoritarian, indulgent, and neglectful (Lamborn et al. 1993). While much international research informs us about their relative prevalence, the predictors of different styles, and their relevant outcomes for children, the respective knowledge base in Germany is still limited. There is considerable need for large-scale studies on parenting providing differentiated insight into parents' goals and practices. This holds true even more so with respect to fathers. Fathers have received increased attention in empirical research internationally for decades (Tamis-LeMon$\mathrm{da} /$ Cabrera 2002), but comparable studies on fathers' roles in parenting have only recently been launched in Germany (Fthenakis/Minsel 2002; Walper/Goedde 2005; Zerle/Krok 2008).

While major interest in research on parenting is devoted to child outcomes, these are not easy to identify because the quality of parenting and children's development share many joint causes. Parenting is not a one-way-street. Rather, it is a product of children's display of behavior and of parents' interpretation of this behavior (Beelmann et al. 2007; Burke/Pardini/Loeber 2008). As is the case for many family processes, selection and adaptation play a role. For example, aggressive children invite harsher parenting and harsh parenting contributes to children's aggressive dispositions (Hoeve et al. 2009; Lösel et al. 2007). Accordingly, any efforts to identify effects of parenting on child development have to take into account reciprocal effects and common factors which influence the quality of parenting as well as child outcomes.

Practices used by parents in daily life are shaped by situational factors, for instance contextual stressors that strain parental well-being and affect parenting skills. Examples for the social embeddedness of parenting are provided by studies about the effects of economic problems and partnership conflicts. There is strong empirical support for the salience of economic stress for family relations, parenting, and children's development (Gershoff et al. 2007; Walper 2008). With respect to the family context of parenting, many studies have pointed out that a low quality of the relationship between mother and father - high interparental conflict in particular - is a major factor undermining the quality of parenting and triggering problem behavior and emotional strain in children (Buehler/Gerard 2002; Cui/Conger 2008; Davies et al. 2002; Hetherington 2006; Walper/Beckh 2006). Given the increasing 
prevalence of single parenting, co-parenting after separation/divorce and stepparenting, variations in family structure need to be considered (Hetherington/Stanley-Hagan 2002; Walper/Krey 2009). Furthermore, a multi-generational view on parenting that embeds parent-child relationships in the larger context of intergenerational affection and power relationships deserves more attention. These questions shall be addressed in pairfam.

Parents' involvement in the parenting role is likely to vary with restrictions they encounter. These result not only from personal and social resources or from children's demands and individual needs but also from competing demands and goals in other domains of life. Melvin Kohn (1969) pointed out how values derived from work experiences feed into parenting. This is a notable example of cross-domain-effects. More recent studies on dual-earner families also address cross-domain effects with respect to work-life balance, indicating that parenting may not only compete with job-related demands but may also have positive, facilitative effects in the domain of work (O'Driscoll/Brough/Kalliath 2006). There is a need for more longitudinal studies enabling research to disentangle the complex relationship between parenting and engagement in other life domains.

\subsection{Intergenerational relationships}

Kinship and intergenerational relationships are structured and organized spatially and temporally in an increasingly complex manner. With regard to its impact on intergenerational relationships, the dramatic social change in intimate relationships is not yet captured by social reporting and creates a significant demand for descriptions of new types of relationships across generations (Teachman/Tedrow 2008). For example, almost nothing is known about grandparent-grandchildren relationships with children in gay/lesbian relationships. Similarly, little do we know about the stability of grandparenting relationships linking children with the parents of a mother or father who no longer lives in the child's household (Ganong 2008). Further, little is known about the incidence of multiple grand-parenthood due to sequential cohabitation or remarriage. Even basic information about the incidence of stepparenthood and the stability of intergenerational relationships after separation and divorce, both for parents and offspring, are difficult to obtain, as is information about intergenerational relationships across national boundaries in immigrant families or in ethnically diverse marriages. Finally, family relationships that transcend the parent-child dyad, especially the relationship between grandparents and grandchildren, have been given more attention only recently (Hank/Buber 2009; Harper 2005; Höpflinger/Hummel/ Hugentobler 2006; Mueller/Elder 2003). Studies in this vein investigate the question of whether the form of grandparent-grandchildren relationships is comparable to the relationships of parents and children (Hoff 2007), or they analyze to what extent (different) generations are mutually entwined (Friedman/Hechter/Kreager 2008).

Intergenerational relations are understood as any form of contact and exchange between generations in one family. Relationship-relevant decisions and behavior have to be modeled as interdependent, as both generations function as the primary environment for the other. Both perspectives have to be included (linked lives). The basic assumption of this theoretical approach for the explanation of intergenerational relationships between adults is that both parties hold mutual expectations. These expectations stem in turn from the shared history of the relationship and the actual situation of both parties. Expectations 
mirror the need for the optimal production of welfare, which does not, however, necessarily contradict the needs and wishes of the other party. Intergenerational relationships are mainly studied using the concept of solidarity (Bengtson 2001) or in the context of work on intergenerational ambivalence (Pillemer/ Lüscher 2004). However, the various types of interaction between generations are not always positive. Intergenerational relations can also be characterized as both positive and negative or merely as ambivalent. In any case, intergenerational expectations significantly determine relationship behavior.

The relationship between parents and children is perhaps one of the most long-lasting relationships in human life. It covers very different stages of life. Against this backdrop, it can be assumed that past experiences and events have an impact on the later form of this relationship (selection and adaptation). Temporal path dependency should be of particular importance: the intergenerational relationship at a particular point in time presumably is significantly shaped by past events, experiences and behavior in this relationship. Hence, the effect of intergenerational reciprocity is investigated most frequently (Silverstein et al. 2002). The focus of this research is also on the effect of transitions in the life course - most especially the separation of parents - on the quality of parent-child relationships (Aquilino 2005; Kalmijn 2008; Kopp/Steinbach 2009) or on the significance of the relationship experience in early childhood for later forms of intergenerational relationships (Cicirelli 1993; Merz/Schuengel/Schulze 2008; Schwarz/Trommsdorff 2005) or for value transmissions. Typical for intergenerational relationships is that they follow a standard sequence of (a)symmetrical stages: While children in their first years are entirely dependent on their parents, after a phase of resource-and-support equilibrium, a trend towards a reverse relationship sets in. Adult children become the main persons of contact and care for their aging parents. Obviously, longitudinal data are indispensable for the appropriate assessment and explanation of what intergenerational relationships are and how they develop.

Despite demographic changes in modern societies, intergenerational relationships are of particularly great significance for family members and are obviously a key mechanism of social integration in functionally differentiated societies. Comparative cultural studies considering different aspects of the multilevel context of intergenerational relationships have been able to demonstrate the impact of institutionalized family structures on their forms (Klaus 2007; Nauck 2009). Based on such findings, those studies gain relevance that inquire into the differences of intergenerational relationships between migrant and native families or into differences between migrant families of different origin and degree of integration. Aside from different cultural backgrounds, various aspects of international migration and the patterns of permanent or temporary separation of generations it causes play an important role in this context.

\section{The conceptual framework of pairfam}

To study issues of couples and family development we suggest a broad conceptual framework from the life course perspective that needs to be augmented by substantive middle-range theories and to be open to different disciplinary perspectives as they prove useful in elaborating the processes involved. Combining economic, sociological, and psychological perspectives, this approach is based on the assumption of cognitively, emo- 
tionally, and culturally bounded rationality (Boudon 2003). According to this individuals try to optimize their subjective well-being over their life course. The life course is perceived as a complex social process (Heinz et al. 2009) which is embedded in a multi-level structure of social dynamics and individual development, consists of different but highly interrelated life domains (multi-dimensionality) and is influenced by the experiences and decisions of the past (path dependency and trajectories).

With regard to subjective well-being, we differentiate between physical-material and social well-being (Esser 1999; Lindenberg 2001; Nauck 2001; Ryan 1991). Physical-material well-being relates to physical (health, material security, avoidance of pain, and stimulation) as well as to psychological needs (emotional well-being, autonomy, and competence). Social well-being relates to the need for social approval (e.g. status), behavioral confirmation, and affection in relation to others (the need for relatedness). In order to satisfy needs in the basic dimensions of subjective well-being, humans pursue individual instrumental goals. The pursuit or the maintenance of biographical states like satisfactory intimate relationships or parenthood, are examples of instrumental goals. Close relationships are instrumental for gaining affection, stimulation, or comfort. Furthermore, objectives can be identified, especially those related to resource acquisition, which are prerequisites for reaching other instrumental goals. For example, a high income is a goal for satisfying needs like comfort. In order to have a high income, however, an appropriate job or a specific kind of education or personal skill is needed, etc.

Attaining instrumental goals calls for the investment of time, money, goods, and physical effort. One can differentiate between direct costs (investment costs and costs for the maintenance of certain biographical statuses like the quality of a close relationship), indirect costs (opportunity costs), as well as follow-up costs (e.g. costs resulting from the partner's or children's behavior). Opportunity costs are conceived as foregone benefits of well-being. Investing in one goal usually means that one cannot invest in other goals and get other benefits.

Individuals act in a given situation structured by opportunities and restrictions such as cultural, social, political, and economic conditions (opportunity structure). These factors influence the scope of action on different levels. On the macro-level we consider for example the demographic structure of the society, cultural patterns, social institutions, legal regulations, regional contexts, the economic situation, the labor market, infrastructure, and effects of social policy. On the meso-level, we consider for example the embeddedness in social networks. The relationship with a partner is assumed to be a particular part of the social environment of a person. For analyzing the development of intimate relationships, a focus on just one partner is insufficient for revealing the complex interaction between partners and generations. Aspects of the household, the couple's relationship, and family lend structure to the situation. On the micro-level, individual resources like time, income, education, physical abilities, cognitive and social competence, health, etc. influence the possibilities for goal attainment. Personal dispositions (norms and values, preferences or aspirations on dimensions of well-being) frame goal-tracking in specific dimensions of well-being. Emotions, personal traits, or biographical experiences are further relevant psychological factors in actors' decision making processes.

The opportunity structure, individual resources, and personal dispositions determine the life domain in which the individual will invest her/his resources in a given situation in 
order to generate subjective well-being. Expectations regarding the degree of instrumentality of goal alternatives and the perceived ability to control outcomes through one's behavior also affect this decision. Actors anticipate future consequences and expected changes in the conditions of their actions. Future life course transitions (the "shadow of the future") gain relevance for decisions on current behavior in two ways. First, the expectation or plan to change family status - an anticipated marriage or childbirth, for example - in the near future may motivate individuals to perform a shift in life domains such as leaving home earlier than planned. Second, actors try to estimate the effects of current behavior on future opportunities of the life course. This is particularly true when transitions lead to irreversible and/or highly committing consequences for the actors in the future life course, as is the case with childbirth. Following the life course perspective, we have to take into account the fact that actors learn from the past and that they are restricted in their degrees of freedom for current actions by past decisions and past behavior. With the longitudinal perspective and the observation of the individual decision processes within a given context of interdependent individuals over a period of time, it will be possible to work out which biographical experiences, needs and demands, as well as which subjective expectations are associated with specific investments in regard to the basic dimensions of subjective well-being.

The advantages of such a conceptual framework are twofold. First, it provides a theoretical heuristic for modeling the high variety of questions concerning intimate relationships and family dynamics from an interdisciplinary perspective. It helps to integrate sociological, economic, and psychological concepts of individual action and decision making over the life course. Second, it provides a general schema for the operationalization of concepts with appropriate instruments of empirical research. Well-grounded middle-range theories then are needed for each substantive issue area for the purpose of linking opportunity structure, individual resources, psychological dispositions, and expected and experienced costs and benefits within the dimensions of well-being for both partners. According to these theories, the general schema for operationalization is to be filled with appropriate measurements pertaining to the main questions of the panel study.

1. Opportunity structure: For each research question within the pairfam panel, the relevant external structural factors have to be specified. For example, if we focus on partnerselection process and close relationships, then information about the "marriage market," partner alternatives, working conditions, mobility, and the distance between the partners if they do not live in the same household is needed. The inclusion of the partner's, parent's, or the children's perspective by implementing a multi-actor design allows for the analysis of processes on the level of the couple and the family as panel information on relevant alteri is available.

2. Individual resources: The resources of the individual, the partner, or the parents define the amount of specific resources that can be invested for achieving subjective well-being. Therefore, resources allocated to individual family members such as time, skill, or income have to be measured separately.

3. Personal dispositions: Considering individual decision-making processes, e.g. investments into the quality and stability of an intimate relationship or the timing of childbearing, individual utility expectations and preferences are important predictors in combina- 
tion with personal traits. These psychological dispositions define the individual motivational structure and should to be modeled specifically for decisions in different life domains.

4. Expected domain-related subjective well-being: In order to capture substitution, compensation, and complementation effects between life-domains in regard to subjective well-being, it is necessary to obtain information about subjectively expected benefits and costs of investments in the respective domains. The panel structure of the data allows then to model these utility expectations as antecedents in the decision-making process, e.g. for the entry into parenthood, for the maintenance of a relationship, or for the care of elderly parents.

5. Intentions: Given the opportunity structure, the individual resources, and personal dispositions as well as the expected benefits and costs pertaining to the basic dimensions of subjective well-being, intentions capture the readiness for transitions in the life course of the individual.

6. Obtained subjective well-being: Since individuals try to achieve well-being through investments in different life domains, the current status of achieved well-being in these life domains and in general are to be monitored continuously. The relationship between the expected benefits compared with the achieved well-being describes the level of perceived satisfaction in the life course domains.

\section{Design of the pairfam panel}

\subsection{Design and fieldwork of wave 1}

The pairfam panel is an annual survey starting with about 12,000 randomly selected respondents of three age groups (see below). These are our anchor persons. Each anchor is asked for permission to interview his partner, children, and parents (his alteri), if available. Thus we have a multi-actor design in which panel information on both the anchor and relevant alteri is available. For reducing respondent burden, in wave 1 we interviewed only anchors and their partners. Beginning with wave 2 the full multi-actor design is used.

The anchor population is defined as all people living in Germany in private households who have sufficient mastery of the German language to follow the interview. We chose a cohort-sequence design with the three birth cohorts 1991-1993, 1981-1983, and 1971-1973. Thus, at the outset of wave 1 we have three age groups: 15-17 years, 25-27 years and 35-37 years. Including these three age groups should provide immediate (crosssectional) information on decisive phases of the life course (therefore this design is sometimes called an "accelerated longitudinal cohort design"). On average, the youngest cohort is in the process of gaining autonomy in relation to their parents and starting their first partnership relations, the middle cohort is expected to consider committed partnership relations and family formation, and in the oldest cohort we expect to see the the highest number of separations of long-term partnership relations. Our goal was to obtain 4,000 interviews from each cohort. 
Due to the high complexity and the volume of content, in the questionnaire we distinguish between core modules, regular extended modules and irregular extra modules (Figure 1). Core modules contain questions repeated annually. They capture relevant information for close description of decision-making processes. In each wave, core modules from all main topics of the pairfam panel are included. Regular extended modules are implemented in the survey questionnaire to gather more detailed information about various subjects of interest. These modules rotate over the different waves. Finally, irregular extra modules contain instruments which have to be included only once, such as the life history calendar (LHC), or very irregularly (e.g. time diaries).

Figure 1: Modularization of the pairfam Panel

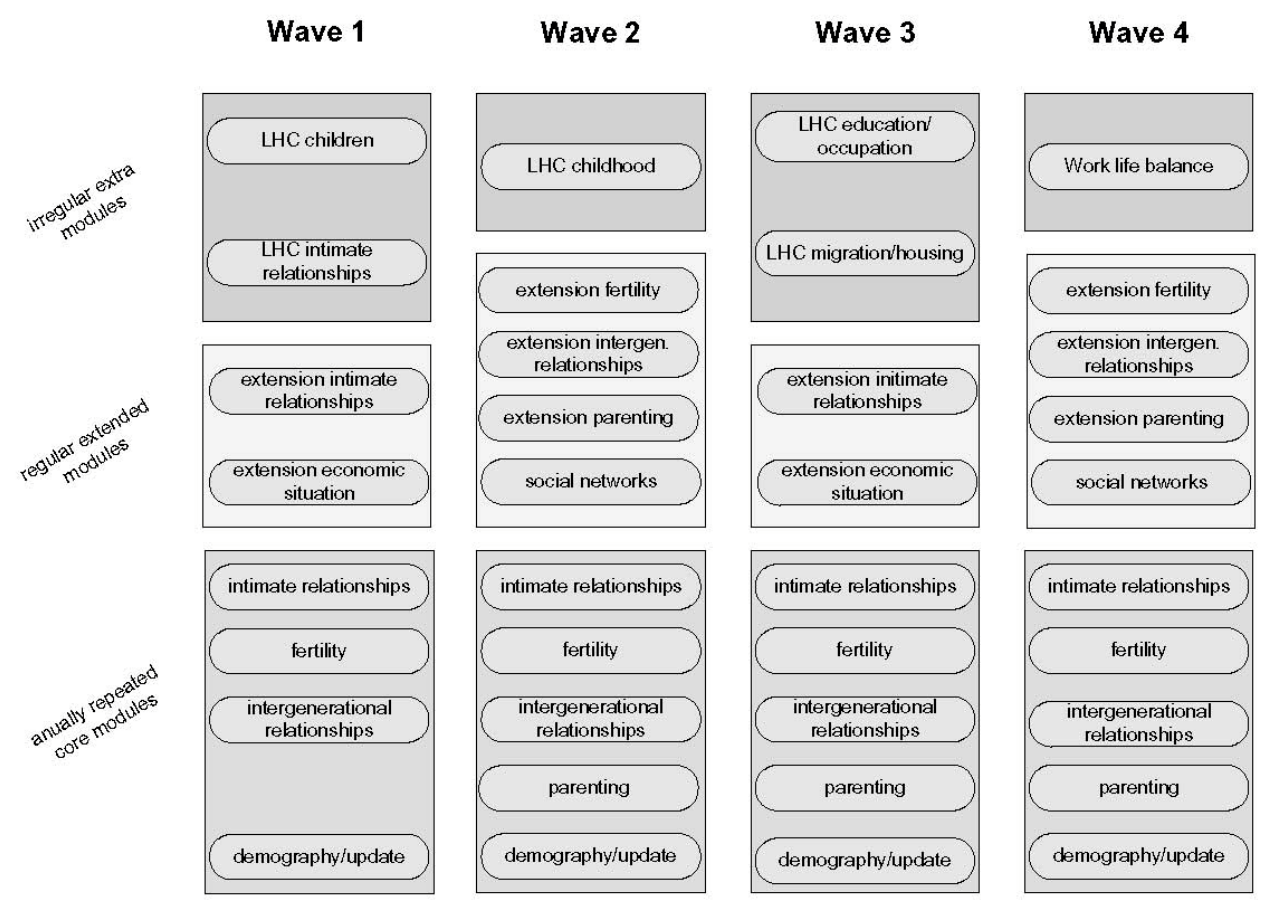

For the initial panel wave in 2008/09, 42,000 addresses were randomly drawn from the population registers of 343 randomly selected communities; 12,402 anchor interviews could be obtained. For the youngest cohort 4,334 interviews were realized, for the middle cohort 4,016, and for the oldest cohort 4,052. The response rate for the initial wave was 36.9 percent overall. It differed between cohorts: 49 percent for the youngest, 33 percent for the middle group, and 32 percent for the oldest. Response rates below 40 percent are common for Germany. The pairfam panel is in this respect not unusual, with the one exception of the relatively high response rate for the youngest cohort.

A low response rate does not necessarily mean that there is a large response bias (Groves/Peytcheva 2008). Recently Blohm and Koch (2009) showed that the German General Social Survey 2008 (ALLBUS), with a response rate of 41 percent, was not bi- 
ased in comparison to an ALLBUS+ study, for which intensive conversion methods generated a response rate of 63 percent. In addition, nonresponse bias is limited in the pairfam data. Frequency distributions do not differ largely from the Mikrozensus 2007, which is a compulsory survey for a one percent sample of the population (Suckow/ Schneekloth 2009). Further, a poststratification weight is included in the data set that optionally can be used for correcting discrepancies.

71 percent of the anchors with a partner gave consent for interviewing their partner. 19 percent of these partners did not return their questionnaire. Overall, 3,729 partner questionnaires were returned, generating a response rate of 51.5 percent. Nonresponse is higher for partners who do not live in the same household.

\subsection{Details on the multi-actor surveys}

Anchor interview: Anchors are interviewed with a Computer-Assisted Personal Interview (CAPI). It includes Computer-Assisted Self-Administered Interview (CASI) segments for sensitive questions. The interview duration averaged 60 minutes in the first wave. There was a large variation in interview length (First Quartile $=38$ minutes, median $=52$ minutes, Third Quartile $=67$ minutes). In wave 2, interviews last 70 minutes on average. A considerable part of the additional interviewing time is needed for acquiring consent for the alteri interviews and for collecting alteri's addresses. Upon completion of the interview, anchors receive a $10 €$ cash incentive which is announced in the advance letter. We do not ask explicitly for re-interviewing consent. Only if the respondent explicitly declines to be re-interviewed will he or she not be contacted again in future waves. In the first wave, two percent of respondents explicitly declined. In future waves, all participants of the previous wave who did not decline explicitly are contacted again. Starting with wave 3, nonparticipating anchors from the last wave are contacted again if they were "soft refusals" (not reachable, no time, etc.). In sum, from the third wave onwards, the design is nonmonotonic with a maximum gap of one wave.

Partner survey: Anchors in a relationship at the time of interview are asked to give their consent to an interview of their partners. This holds independently of the cohabitation status of the couple. In case of consent, the partner receives a 24-page Paper and PencilQuestionnaire (PAPI). The questionnaire is handed out by the interviewer, left behind with the anchor or sent to the partner, depending on the situation and the anchor's preference. The questionnaire can be collected by the interviewer or sent back by the partner in the return envelope provided. After sending back the questionnaire, the partner receives a $5 €$ ticket for a charity lottery.

Child interview: The child survey targets all biological children, adopted children, foster children and stepchildren of the anchor between eight and fifteen years old who are living in the anchor's household. To reduce the overall burden, the survey starts with only one child (the youngest eligible child) in wave 2. In the following waves this child will be asked to give follow-up interviews as long as he or she still lives in the anchor's household. In addition, all children who had their $8^{\text {th }}$ birthday during the previous year are included in the child survey. After obtaining permission to contact the children from the an- 
chor, a 15-minute CAPI interview with the selected child(ren) is scheduled. There is a $5 €$ gift to children in the survey as an incentive. Participants from the child survey who grow out of the age range upon their sixteenth birthday will be included in the anchor sample of the study.

Parenting survey: The parenting survey corresponds to the child survey. In each wave, the anchor and his/her partner receive a PAPI-questionnaire for each child participating in the child survey. The questionnaire is on parenting from the viewpoint of the parents. The anchor is asked for consent and whether a questionnaire can be given to his or her partner, too. For this survey, no incentive is given. The handover process of the questionnaire is as follows: The anchor receives the questionnaire during the interview and it is collected after the interview or sent back in a return envelope. The partner receives a parenting questionnaire with the partner survey questionnaire and sends it or gives it back with the partner questionnaire.

Further, we collect information on children below age eight in the anchor interview and in the partner questionnaire. Beginning with newborns in wave 2, we will follow up on all children born since the last interview with age-specific questions until they become eight (and enter the child survey).

Parents' survey: The parents' survey is an annual mail survey of the parents of the anchor. Eligible for selection are biological parents, adoptive parents, and stepparents with whom the anchor is in contact (with a maximum of three). Biological parents are almost always approached for an interview. Only if the anchor is living with adoptive parents since early childhood do those adoptive parents replace biological parents in the study. Among existing stepparents, the stepfather is preferred as the third parent in the survey. Only in his absence will the stepmother be selected. During the anchor interview, consent to approach the parents is obtained and addresses are collected. The field organization then mails a questionnaire of about 26 pages (16 pages in odd-numbered waves). The accompanying cover letter explains which children (and grandchildren) the questionnaire pertains to. Parents are asked to fill in the questionnaire and return it using the provided prepaid envelopes. Upon receiving the completed questionnaire, a thank-you letter is sent out that includes a $5 €$ ticket for a charity lottery.

\subsection{Guiding principles of questionnaire construction}

For a panel survey, respondent retention is essential. For this reason, we have tried to make the survey as attractive as possible and to reduce the burden of participation as far as possible. On the positive side, other than hoping that our questionnaire is interesting, we rely on conditional cash incentives due to our experience with a pilot study (Castiglioni/Pforr/Krieger 2008). In light of budgetary restrictions, we decided to give $10 €$ for anchors and $5 €$ for alteri. The idea of using lottery tickets stems from the positive experience of the German Socioeconomic Panel (GSOEP).

For reducing respondents' time burden we made full use of the technical possibilities provided by CAPI. Therefore, we decided to use routing extensively. This enables us to avoid asking unnecessary questions to respondents, as we can tailor the questionnaire to the respondents' specific situations. This comes at the cost of a long and sophisticated 
CAPI program code but helps us to save interview time and thus to keep our costs down and the respondent's time burden as light as possible. Additionally, it minimizes the possibility of inconsistent answers.

Another feature of the pairfam panel is the use of Dependent Interviewing (DI) in the anchor interview. With DI we feed forward information collected in the prior wave to the present interview. We make extensive use of DI and preload over 300 variables. Further, we decided on using a proactive DI approach, asking respondents to validate whether a given fact from the prior wave has changed or is still correct. With DI, the respondent has a simpler cognitive task at hand. He or she can simply confirm the information instead of producing a complete answer all over again. This saves us valuable interview time and the respondent's task is made easier.

DI is also used for collecting information on the life course. We decided to collect anchors' life courses in an event history format, i.e. in each wave we ask retrospectively about changes since the last interview and their timing. This is done for partnership, employment and residential history. To reduce respondents' burden we use a graphic event history calendar (EHC) to collect this information. A timeline is presented which already contains preloaded information from the last wave as the starting point. Respondents (with the help of the interviewer) then enter information on their life course interactively in the EHC. Thus, the interviewer and the respondent can see and edit a graphic account of the life course over the last year. The combination of DI and EHC - used for the first time in a large population survey - should ease the cognitive task of the respondent and produce more consistent data with less measurement error.

Our final strategy for reducing respondent burden is the use of CASI when asking very sensitive information or questions that might be very sensitive in the presence of other household members. The interviewer's laptop is handed over to the respondent, who then can fill in the questions autonomously. Thus, we create privacy for the respondent while still being able to use the advantages of a computerized interview. The data are available immediately and can be used for routing in later parts of the interview. After completion of the CASI segment, the laptop is returned to the interviewer.

\section{Concluding remarks}

The pairfam project is a cooperative effort of the University of Bremen, the Chemnitz University of Technology, the University of Mannheim and the Ludwig-Maximilians University of Munich. Principal investigators are Josef Brüderl (Mannheim), Johannes Huinink (Bremen), Bernhard Nauck (Chemnitz) and Sabine Walper (Munich). The design of the first three waves was coordinated by Johannes Huinink, the subsequent waves will be organized by Bernhard Nauck. The pairfam project now is funded as a project of the "Long-term Program" of the German Research Foundation, which shall allow continuing the panel study for 14 waves in total.

Although designed within a largely coherent conceptual framework and not for multipurpose data collection, the pairfam data are a collective good of the scientific community. These data sets are purposively produced as scientific use files. Important benchmarks of the scientific value of pairfam are the demand of scientists from various disci- 
plines, institutions, and nations for the data produced as well as the scientific output based on the analysis of pairfam data. Accordingly, efforts are being made to release the data of the respective waves as early as possible to the scientific community while meeting high standards of usability. This includes support provided in personal consultation and on internet platforms, from which extensive material on the instruments and field reports are downloadable. Also, user conferences will be held regularly in which the data structure and its analytic capacity are explained to potential users. Similarly, methods workshops are planned in which results from the analysis of pairfam data are shared and discussed.

The character of the pairfam data as a scientific use file implies that these data are exclusively provided for scientific analyses. Precautions are taken to comply with and enforce German privacy laws, especially with regard to anonymity and disaggregation, and to protect the personal rights of the interviewees and their family members in these sensitive matters of intimate relationships. Within these limits, pairfam data are provided to all upon submission and approval of a research proposal.

The data of the first pairfam wave is available for scientific analyses (www.pairfam. de). With the next waves, the survey design of pairfam will be rounded out. At the same time, pairfam has to remain flexible enough to take on future challenges. Although continuity in the survey program (and the longitudinal analyses this makes possible) is the primary goal of the survey, the survey design can accommodate changing demand for data. New methods of data collection will be considered, too. It is also possible for interested researchers to use pairfam as a platform for the implementation of in-depth studies of particular issues. The use of pairfam data for comparative research will be supported. In any case, the data to be generated will provide a sound and profound basis for improving fundamental research on couples and family dynamics.

\section{References}

Amato, P. R. (1996). Explaining the intergenerational transmission of divorce. Journal of Marriage and the Family, 58, pp. 628-640.

Amato, P. R., Booth, A. \& Johnson, D. R. (2007). Alone together: How marriage in America is changing. Cambridge: Harvard University Press.

Arránz Becker, O. (2008). Was hält Partnerschaften zusammen? Psychologische und soziologische Erklärungsansätze zum Erfolg von Paarbeziehungen. Wiesbaden: VS Verlag für Sozialwissenschaften.

Aquilino, W. S. (2005). Impact of family structure on parental attitudes toward the economic support of adult children over the transition to adulthood. Journal of Family Issues, 26, pp. 143-167.

Becker, G. S. (1991). A treatise on the family. Cambridge: Harvard University Press.

Beelmann, A., Stemmler, M., Lösel, F. \& Jaursch, S. (2007). Zur Entwicklung externalisierender Verhaltensprobleme im Übergang vom Vor- zum Grundschulalter. Kindheit und Entwicklung, 16, pp. 229-239.

Bengtson, V. L. (2001). Beyond the nuclear family: The increasing importance of multigenerational bonds. Journal of Marriage and the Family, 63, pp. 1-16.

Bernardi, L., Keim, S. \& von der Lippe, H. (2007). Social influences on fertility: A comparative mixed methods study in Eastern and Western Germany. Journal of Mixed Methods Research, 1, pp. 23-47.

Blohm, M. \& Koch, A. (2009). Ausschöpfungsquoten und Stichprobenqualität am Beispiel des ALLBUS 2008: Führt eine höhere Ausschöpfung zu anderen/besseren Umfrageergebnissen? Presentation at the workshop „Qualität von Großerhebungen“, Nürnberg, September $3^{\text {rd }}-4^{\text {th }}, 2009$. 
Blossfeld, H.-P. \& Drobnič, S. (Eds) (2002). Careers of couples in contemporary society. From male breadwinner to dual-earner families. New York: Oxford University Press.

Bodenmann, G. (2006). Positionsbestimmungen in der Paar- und Familienpsychologie. Zeitschrift für Familienforschung, 18, pp. 148-170.

Bodenmann, G., Charvoz, L., Bradbury, T. N., Bertoni, A., Iafrate, R., Giuliani, C., Banse, R. \& Behling, J. (2007). The role of stress in divorce: A retrospective study in three nations. Journal of Social and Personal Relationships, 24, pp. 707-728.

Boudon, R. (2003). Beyond rational choice theory. Annual Review of Sociology, 29, pp. 1-21.

Brose, N. (2008). Entscheidung unter Unsicherheit - Familiengründung und -erweiterung im Erwerbsverlauf. Kölner Zeitschrift für Soziologie und Sozialpsychologie, 60, pp. 30-52.

Brüderl, J. (2004). Die Pluralisierung partnerschaftlicher Lebensformen in Westdeutschland und Europa. Aus Politik und Zeitgeschichte B119/2004, pp, 3-10.

Bühler, C. (2008). On the structural value of children and its implication on intended fertility in Bulgaria. Demographic Research, 18, 569-610.

Buehler, C. \& Gerard, J. M. (2002). Marital conflict, ineffective parenting and children's and adolescents' maladjustment. Journal of Marriage and Family, 64, pp. 78-92.

Burke, J. D., Pardini, D. A. \& Loeber, R. ( 2008). Reciprocal relationships between parenting behavior and disruptive psychopathology from childhood through adolescence. Journal of Abnormal Child Psychology, 36, pp. 679-692.

Castiglioni, L., Pforr, K. \& Krieger, U. (2008). The effect of incentives on response rates and panel attrition: Results of a controlled experiment. Survey Research Methods, 2, pp. 151-158.

Cicirelli, V. G. (1993). Attachment and obligation as daughters' motives for caregiving behavior and subsequent effect on subjective burden. Psychology and Aging, 8, pp. 144-155.

Conger, K. J., Rueter, M. A., \& Conger, R. D. (2000). The role of economic pressure in the lives of parents and their adolescents: The Family Stress Model. In: L. J. Crockett \& R. K. Silbereisen (Eds), Negotiating adolescence in times of social change. Cambridge: Cambridge University Press, pp. 201-233.

Cui, M. \& Conger, R. D. (2008). Parenting behavior as mediator and moderator of the association between marital problems and adolescent maladjustment. Journal of Research on Adolescence, 18, pp. 261-284.

Davies, P. T., Harold, G. T., Goeke-Morey, M. C., Cummings, E. M., Shelton, K. \& Rasi, J. A. (2002). Child emotional security and interparental conflict. Monographs of the Society for Research in Child Development, 67 (Serial No. 270).

Diekmann, A. \& Engelhardt, H. (1999). The social inheritance of divorce: Effects of parent's family type in postwar Germany. American Sociological Review, 64, pp. 783-793.

Diefenbach, H. (2000). Intergenerationale Scheidungstransmission in Deutschland. Die Suche nach dem „missing link" zwischen Ehescheidung in der Elterngeneration und Ehescheidung in der Kindgeneration. Würzburg: Ergon.

Diewald, M. (2003). Kapital oder Kompensation? Erwerbsbiographien von Männern und die sozialen Beziehungen zu Verwandten und Freunden. Berliner Journal für Soziologie, 16, pp. 213-238.

Elder, G. H., Jr. (1994). Time, human agency, and social change: Perspectives on the life course. Social Psychology Quarterly, 57, pp. 4-15.

Esser, H. (1999). Soziologie: Spezielle Grundlagen, Band 1. Frankfurt am Main: Campus.

Feldhaus, M. \& Huinink, J. (Eds) (2008). Neuere Forschungsperspektiven zur Beziehungs- und Familienentwicklung. Würzburg: Ergon.

Fincham, F. D. (2004). Attributions in close relationships: From balkanization to integration. In: M. Hewstone \& M. Brewer (Eds), Social cognition. Malden: Blackwell Publishing, pp. 165-193.

Fincham, F. D., Stanley, S. M. \& Beach, S. R. H. (2007). Transformative processes in marriage: An analysis of emerging trends. Journal of Marriage and Family, 69, pp. 275-292.

Franiek, S. \& Reichle, B. (2007). Elterliches Erziehungsverhalten und Sozialverhalten im Grundschulalter. Kindheit und Entwicklung, 16, pp. 240-249.

Friedman, D., Hechter, M. \& Kreager, D. (2008). A theory of the value of grandchildren. Rationality and Society, 20, pp. 31-63. 
Fthenakis, W. E. \& Minsel, B. (2002). Die Rolle des Vaters in der Familie Stuttgart: Kohlhammer, (Schriftenreihe des BMFSFJ, Band 213).

Fuhrer, U. (2005). Lehrbuch Erziehungspsychologie. Bern: Huber.

Gabriel, B. \& Bodenmann, G. (2006). Elterliche Kompetenzen und Erziehungskonflikte. Eine ressourcenorientierte Betrachtung von familiären Negativdynamiken. Kindheit und Entwicklung, 15, pp. 918.

Ganong, L. (2008). Intergenerational relationships in stepfamilies. In: J. Pryor (Ed.), The international handbook of stepfamilies: Policy and practice in legal, research, and clinical environments. Hoboken, NJ: Wiley, pp. 394-422.

Gershoff, E. T., Aber, J. L., Raver, C. C. \& Lennon, M. C. (2007). Income is not enough: Incorporating material hardship into models of income associations with parenting and child development. Child Development, 78, pp. 70-95.

Grossmann, K. \& Grossmann, K. E. (2004). Bindungen - das Gefüge psychischer Sicherheit. Stuttgart: Klett-Cotta.

Groves, R. \& Peytcheva, E. (2008). The impact of nonresponse rates on nonresponse bias: A metaanalysis. Public Opinion Quarterly, 72, pp.167-189.

Hank, K. (2001). Regional fertility differences in Western Germany: An overview of the literature and recent descriptive findings. International Journal of Population Geography, 7, pp. 243-257.

Hank, K. (2003a). Eine Mehrebenenanalyse regionaler Einflüsse auf die Familiengründung westdeutscher Frauen in den Jahren 1984 bis 1999. Kölner Zeitschrift für Soziologie und Sozialpsychologie, 55, pp. 79-98.

Hank, K. (2003b). The differential influence of women's residential district on the risk of entering first marriage and motherhood in Western Germany. Population and Environment, 25, pp. 3-21.

Hank, K. \& Buber, I. (2009). Grandparents caring for their grandchildren. Findings from the 2004 Survey of Health, Ageing, and Retirement in Europe. Journal of Family Issues, 30, pp.53-73.

Harper, S. (2005). Grandparenthood. In: M. L. Johnson (Ed.), The Cambridge handbook of age and ageing. Cambridge: Cambridge University Press, pp. 422-428.

Heinz, W., Huinink, J., Swader, C. \& Weymann, A. (2009). Fundamental conceptual frameworks: General introduction. In: W. Heinz, J. Huinink \& A. Weymann (Eds), The life course reader: Individuals and society across time. Frankfurt am Main: Campus, pp. 15-30.

Hetherington, E. M. (2006). The influence of conflict, marital problem solving and parenting on children's adjustment in nondivorced, divorced, and remarried families. In: A. Clarke-Stewart \& J. Dunn (Eds), Families count: Effects on child and adolescent development. Cambridge: Cambridge University Press, pp. 203-237.

Hetherington, E. M. \& Stanley-Hagan, M. M. (2002). Parenting in divorced and remarried families. In: M. H. Bornstein (Ed.), Handbook of parenting: Vol. 3: Being and becoming a parent. Mahwah, NJ: Lawrence Erlbaum Associates, pp. 287-315 (2nd edition).

Hill, P. (Ed.) (2004). Interaktion und Kommunikation - Eine empirische Studie zu Alltagsinteraktionen, Konflikten und Zufriedenheit in Partnerschaft. Würzburg: Ergon.

Hillmann, K.-H. (2003). Wertewandel. Würzburg: Carolus.

Hoehn, C., Avramov, D. \& Kotovska, I. (Eds) (2008). People, population change and policies. New York \& Heidelberg: Springer.

Höpflinger, F., Hummel, C. \& Hugentobler, V. (2006). Enkelkinder und ihre Grosseltern. Intergenerationelle Beziehungen im Wandel. Zürich: Seismo.

Hoeve, M. H., Dubas, J. S., Eichelsheim, V. I., Laan, P. H. v. d., Smeenk, W., \& Gerris, J. R. M. (2009). The relationship between parenting and delinquency: A meta-analysis. Journal of Abnormal Child Psychology, 37, pp. 749-775.

Hoff, A. (2007). Patterns of intergenerational support in grandparent-grandchild and parent-child relationships in Germany. Ageing and Society, 27, pp. 643-665.

Huinink, J. (1995). Warum noch Familie? Frankfurt am Main: Campus.

Huinink, J. (2005). Zur Positionsbestimmung der empirischen Familiensoziologie. Zeitschrift für Familienforschung, 18, pp. 212-252. 
Huinink, J. \& Röhler, H. K. A. (2005). Liebe und Arbeit in Paarbeziehungen. Zur Erklärung geschlechtstypischer Arbeitsteilung in nichtehelichen und ehelichen Lebensgemeinschaften. Würzburg: Ergon.

Huinink, J. \& Feldhaus, M. (2009). Family research from the life course perspective. International Sociology, 24, pp. 299-324.

Kalmijn, M. (2008). The effects of seperation and divorce on parent-child relationships in ten European countries. In: C. Saraceno (Ed.), Families, ageing and social policy. Intergenerational solidarity in European welfare states. Cheltenham/Northamptom: Elgar, pp. 170-193.

Karney, B. R. \& Bradbury, T. N. (1995). The longitudinal course of marital quality and stability: A review of theory, method, and research. Psychological Bulletin, 118, pp. 3-34.

Klaus, D. (2007). Intergenerativer Austausch im Ländervergleich. Ergebnisse aus dem Value-ofChildren Projekt. In: K. S. Rehberg (Ed.), Die Natur der Gesellschaft. Verhandlungen des 33. Kongresses der Deutschen Gesellschaft für Soziologie in Kassel 2006. Frankfurt am Main: Campus, pp. 4915-4924.

Kohli, M., Albertini, M. \& Künemund, H. (2010): Linkages among adult family generations: Evidence from comparative survey research. In: P. Heady \& M. Kohli (Eds): Family, kinship and state in contemporary Europe. Vol. 3: Perspectives on theory and policy. Frankfurt am Main: Campus, pp. 195-220.

Kohn, M. L. (1969). Class and confomity: A study in values. Chicago: The University of Chicago Press.

Kopp, J. \& Steinbach, A. (2009). Generationenbeziehungen. Ein Test der intergenerational-stakeHypothese. Kölner Zeitschrift für Soziologie und Sozialpsychologie, 61, pp. 283-294.

Kreyenfeld, M. (2003). Crisis or adaptation - reconsidered: A comparison of East and West German fertility patterns in the first six years after the 'Wende'. European Journal of Population, 19, pp. 303329.

Kurz, K. (2005). Die Familiengründung von Männern im Partnerschaftskontext. In: A. Tölke \& K. Hank (Eds.), Männer - Das „,vernachlässigte“ Geschlecht in der Familienforschung. Wiesbaden: VS Verlag für Sozialwissenschaften, pp. 178-197.

Lamborn, S. D., Mounts, N. S., Steinberg, L. \& Dornbusch, S. M. (1991). Patterns of competence and adjustment among adolescents from authoritative, authoritarian, indulgent, and neglectful families. Child Development, 62, pp. 1049-1065.

Lengerer, A., \& Klein, T. (2007). Der langfristige Wandel partnerschaftlicher Lebensformen im Spiegel des Mikrozensus. Wirtschaft und Statistik,4, pp. 433-447.

Lesthaeghe, R. (2002). Meaning and choice: Value orientations and life course decisions. The Hague \& Brussels: NIDI CBGS.

Lesthaeghe, R. \& Surkyn, J. (2004). Value orientations and the second demographic transition (SDT) in Northern, Western and Southern Europe: An update. Demographic Research, 3, pp. 45-86.

Liefbroer, A. C. (2005). The impact of perceived costs and rewards of childbearing on entry into parenthood: Evidence from a panel study. European Journal of Population, 21, pp.367-391.

Liefbroer, A. C. (2009). Changes in family size intentions across young adulthood. A life course perspective. European Journal of Population, 25, pp. 363-386.

Lindenberg, S. (2001). Intrinsic motivation in a new light. Kyklos, 54, pp. 317-342.

Lösel, F., Jaursch, S., Beelmann, A., \& Stemmler, M. (2007). Prävention von Störungen des Sozialverhaltens - Entwicklungsförderung in Familien: das Eltern- und Kindertraining EFFEKT. In W. v. Suchodoletz (Ed.), Prävention von Entwicklungsstörungen. Göttingen: Hogrefe, pp. 215-234.

Lyons, K. S. \& Sayer, A. G. (2005). Longitudinal dyad models in family research. Journal of Marriage and Family, 67, pp. 1048-1060.

Maccoby, E. E. \& Martin, J. A. (1983). Socialization in the context of the family: Parent-child interaction. In: E. M. Hetherington (Ed.), Handbook of child psychology: Vol. 4.: Socialization, personality, and social development. New York: Wiley, pp. 1-101.

Mayer, K.U. (2009). New directions in life course research. Annual Review of Sociology, 35, pp. 413433.

Merz, E.-M., Schuengel, C. \& Schulze, H.-J. (2008). Inter-generational relationships at different ages: An attachment perspective. Ageing and Society, 28, pp. 717-736. 
Mikulincer, M. \& Goodman, G.S. (Eds.) (2006). Dynamics of romantic love. attachment, caregiving, and sex. New York: Guilford Press.

Miller, W. B., Severy, L. J. \& Pasta, D. J. (2004). A framework for modelling fertility motivation in couples. Population Studies, 58, pp. 193-205.

Müller-Burhop, M. (2008). Elternwünsche. Eine empirische Studie über Wünsche und Vorstellungen junger Eltern und daraus folgende Konsequenzen für Politik und Gesellschaft. Würzburg: Ergon.

Mueller, M. M. \& Elder, G. H., Jr. (2003). Family contingencies across the generations: Grandparentgrandchild relationships in holistic perspective. Journal of Marriage and Family, 65, pp. 404-417.

Nauck, B. (2001). Der Wert von Kindern für ihre Eltern. „Value of Children“ als spezielle Handlungstheorie des generativen Verhaltens und von Generationenbeziehungen im interkulturellen Vergleich. Kölner Zeitschrift für Soziologie und Sozialpsychologie, 53, pp. 407-435.

Nauck, B. (2007). Value of children and the framing of fertility: Results from a cross-cultural comparative survey in 10 societies. European Sociological Review, 23, pp. 615-629.

Nauck, B. (2009). Patterns of exchange in kinship systems in Germany, Russia, and the People's Republic of China. Journal of Comparative Family Studies, 40, pp. 255-278.

O'Driscoll, M., Brough, P., \& Kalliath, T. (2006). Work-family conflict and facilitation. In: F. Jones, R. J. Burke \& M. Westman (Eds), Work-life balance: A psychological perspective. Hove \& New York: Psychology Press, pp. 117-142.

Petermann, U. \& Petermann, F. (2006). Erziehungskompetenz. Kindheit und Entwicklung, 15, pp. 1-8.

Peuckert, R. (2008). Familienformen im sozialen Wandel. Wiesbaden: Verlag für Sozialwissenschaften ( $7^{\text {th }}$ edition).

Pillemer, K. \& Lüscher, K. (2004). Intergenerational ambivalences: New perspectives on parent-child relations in later life. Oxford: Elsevier.

Pryor, J. \& Rodgers, B. (2001). Children in changing families. Life after parental separation. Oxford: Blackwell.

Randall, A. K. \& Bodenmann, G. (2009). The role of stress on close relationships and marital satisfaction. Clinical Psychology Review, 29, pp.105-115.

Rindfuss, R. R. \& Brewster, K. L. (1996). Childrearing and fertility. Population and Development Review, 22, Issue Supplement: Fertility in the United States: New patterns, new theories, pp. 258-289.

Reichle, B. \& Gloger-Tippelt, G. (2007). Familiale Kontexte und sozial-emotionale Entwicklung. Kindheit und Entwicklung, 16, pp. 199-208.

Ryan, R. M. (1991). The nature of the self in autonomy and relatedness. In: J. Strauss \& G. R. Goethals (Eds.), The self: Interdisciplinary approaches. New York: Springer, pp. 208-238.

Schneewind, K. A. \& Ruppert, S. (1995). Familien gestern und heute: ein Generationenvergleich über 16 Jahre. München: Quintessenz.

Schneider, N., Limmer, R. \& Ruckdeschel, K. (2002). Mobil, flexibel, gebunden. Familie und Beruf in der Gesellschaft. Frankfurt am Main: Campus.

Schneider, N. F., \& Meil, G. (Eds) (2009). Mobile living across Europe I: Relevance and diversity of job-related spacial mobility in six European countries. Opladen \& Farmington Hills, MI: Barbara Budrich Publishers.

Schröder, J. \& Brüderl, J. (2008). Der Effekt der Erwerbstätigkeit von Frauen auf die Fertilität: Kausalität oder Selbstselektion. Zeitschrift für Soziologie, 37, pp. 117-136.

Schröder, J. \& Pforr, K. (2009). Der aktuelle Forschungsstand zum Zusammenhang zwischen Erwerbstätigkeit und Fertilität bei Frauen. Zeitschrift für Familienforschung, 21, pp. 218-244.

Schwarz, B. \& Trommsdorff, G. (2005). The relation between attachment and intergenerational support. European Journal of Ageing, 2, pp. 192-199.

Seltzer, J. A., Bachrach, C. A., Bianchi, S. M., Bledsoe, C. H., Casper, L. M., Chase-Lansdale, P. L., DiPrete, T. A., Hotz, V. J., Morgan, S. P., Sanders, S. G. \& Thomas, D. (2005). Explaining family change and variation: Challenges for family demographers. Journal of Marriage and Family, 67, pp. 908-925.

Silverstein, M., Conroy, S. J., Wang, H., Giarrusso, R. \& Bengtson, V. L. (2002). Reciprocity in parentchild relations over the adult life course. Journal of Gerontology: Social Sciences, 57, pp. 3-13. 
Skinner, E., Johnson, S. \& Snyder, T. (2005). Six dimensions of parenting: A motivational model. Parenting: Science \& Practice, 5, pp. 175-235.

Smart, C., Neale, B. \& Wade, E. (2001). The changing experience of childhood: Families and divorce. Cambridge: Polity.

Stein, P. \& Pavetic, M. (2008). Entwicklung eines Modells zur Analyse von Fertilitätsentscheidungen in Partnerschaften. In: K. S. Rehberg (Ed.), Die Natur der Gesellschaft: Verhandlungen des 33. Kongresses der Deutschen Gesellschaft für Soziologie in Kassel 2006. Frankfurt am Main: Campus, pp. 2152-2167.

Stöbel-Richter, Y., Goldschmidt, S., Borkenhagen, A., Kraus, U., Weidner, K. (2008). Entwicklung in der Reproduktionsmedizin - mit welchen Konsequenzen müssen wir uns auseinandersetzen? Zeitschrift für Familienforschung, 20, pp. 34-61.

Suckow, J. \& Schneekloth, U. (2009). Beziehungen und Familienleben in Deutschland: Welle 1. Methodological Report. München: Infratest.

Tamis-LeMonda, C. S. \& Cabrera, N. (Eds) (2002). Handbook of father involvement: Multidisciplinary perspectives. Mahwah, NJ: Lawrence Erlbaum Associates.

Teachman, J. \& Tedrow, L. (2008). The demography of stepfamilies in the United States. In: J. Pryor (Ed.), The International handbook of stepfamilies: Policy and practice in legal, research, and clinical environments. Hoboken, NJ: Wiley, pp. 3-29.

Teubert, D. \& Pinquart, M. (2009). Coparenting: Das elterliche Zusammenspiel in der Kindererziehung. Psychologie in Erziehung und Unterricht, 56, pp. 161-171.

Walper, S. (2008). Sozialisation in Armut. In: K. Hurrelmann, H. Grundmann \& S. Walper (Eds.), Handbuch der Sozialisationsforschung. Weinheim: Juventa, pp. 204-214.

Walper, S. \& Beckh, K. (2006). Adolescents' development in high-conflict and separated families. Evidence from a German longitudinal study. In: A. Clarke-Stewart \& J. Dunn (Eds), Families count: Effects on child and adolescent development. Cambridge: Cambridge University Press, pp. 238-270.

Walper, S., Guglhör-Rudan, A., Thönnissen, C., Wendt, E.-V. \& Beckh, K. (2008). Paarbeziehungen im Jugend- und Erwachsenenalter: Entwicklungsbedingte Besonderheiten und Einflüsse der Herkunftsfamilie. In: J. Huinink \& M. Feldhaus (Eds), Neuere Entwicklungen in der Beziehungs- und Familienforschung. Vorstudien zum Beziehungs- und Familienentwicklungspanel. Würzburg: Ergon, pp. 115-150.

Walper, S. \& Gödde, M. (2005). Jugendliche und ihre Beziehung zum Vater. Ein Vergleich von Kern-, Trennungs- und Stieffamilien. In: B. Schuster, H.-P. Kuhn \& H. Uhlendorf (Eds.), Entwicklung in sozialen Beziehungen - Heranwachsende in ihrer Auseinandersetzung mit Familie, Freunden und Gesellschaft. Stuttgart: Lucius \& Lucius, pp. 65-89.

Walper, S. \& Krey, M. (2009). Familienbeziehungen nach Trennungen. In: K. Lenz \& F. Nestmann (Eds), Persönliche Beziehungen. Weinheim: Juventa, pp. 715-743.

Walper, S. \& Wendt, V. (2010) (Eds). Partnerschaften und die Beziehungen zu Eltern und Kindern: Befunde zur Beziehungs- und Familienentwicklung in Deutschland. Würzburg: Ergon.

Walper, S. \& Wendt, E.-V. (2010). Partnerschaften und die Beziehungen zu Eltern und Kindern: Eine Einführung. In: S. Walper \& E.-V. Wendt (Eds.), Partnerschaften und die Beziehungen zu Eltern und Kindern. Befunde zur Beziehungs- und Familienentwicklung in Deutschland. Würzburg: Ergon, pp. 7-34.

Walsh, F. (Ed.). (2003). Normal family processes. Growing diversity and complexity. New York: The Guilford Press.

Zeller-Steinbrich, G. (2008). Fertilitätsbehandlung, Reproduktionsmotive und die Fähigkeit zur Elternschaft. Analytische Kinder- und Jugendlichen-Psychotherapie, 39, pp. 447-472.

Zerle, C. \& Krok, I. (Eds.) (2008). Null Bock auf Familie? Der schwierige Weg junger Männer in die Vaterschaft. Gütersloh: Verlag Bertelsmann Stiftung.

Submitted on/Eingereicht am: 15.04.2010

Accepted on/Angenommen am: 09.12.2010 
Addressen of the authors/Anschriften der Autorinnen und Autoren:

Prof. Dr. Johannes Huinink (Korrespondenzautor/Corresponding author) EMPAS, Universität Bremen

Celsiusstraße 1 (FVG)

28359 Bremen

E-Mail: huinink@empas.uni-bremen.de

Prof. Dr. Josef Brüderl

Universität Mannheim

Prof. Dr. Bernhard Nauck

Universität Chemnitz

Prof. Dr. Sabine Walper

Ludwig-Maximilians-Universität München

Dr. Laura Castiglioni

MZES, Universität Mannheim

Dr, Michael Feldhaus

EMPAS, Universität Bremen

E-Mail:bruederl@uni-mannheim.de walper@edu.uni-muenchen.de Laura.Castiglioni@mzes.uni-mannheim.de feldhaus@empas.uni-bremen.debruederl@uni-mannheim.de 